\title{
Nonmyristoylated Abl Proteins Transform a Factor-Dependent Hematopoietic Cell Line
}

\author{
GEORGE Q. DALEY, ${ }^{1}$ RICHARD A. VAN ETTEN,${ }^{1} \dagger$ PETER K. JACKSON,${ }^{1} \ddagger$ \\ ANDRE BERNARDS, ${ }^{2} \S$ AND DAVID BALTIMORE ${ }^{1,2 *}$ \\ The Whitehead Institute for Biomedical Research, Nine Cambridge Center, \\ Cambridge, Massachusetts 02142, ${ }^{1}$ and The Rockefeller University, \\ 1230 York Avenue, New York, New York 10021 2
}

Received 7 November 1991/Accepted 15 January 1992

\begin{abstract}
N-terminal myristoylation can promote the association of proteins with the plasma membrane, a property that is required for oncogenic variants of Src and Abl to transform fibroblastic cell types. The P210 protein of chronic myelogenous leukemia cells is not myristoylated and does not stably transform NIH 3T3 fibroblasts; however, it will transform lymphoid and myeloid cell types in vitro and in vivo, suggesting that myristoylation is not required for Abl variants to transform hematopoietic cells. To test this hypothesis, we introduced point mutations that disrupt myristoylation into two activated Abl proteins, $v$-Abl and a deletion mutant of $\mathrm{c}-\mathrm{Abl}(\triangle \mathrm{XB})$, and examined their ability to transform an interleukin-3-dependent lymphoblastoid cell line, Ba/F3. Neither of the nonmyristoylated Abl proteins transformed NIH 3 T3 fibroblasts, but like $\mathrm{P210}^{\text {bcr/abl }}$, both were capable of transforming the $\mathrm{Ba} / \mathbf{F} 3$ cells to factor independence and tumorigenicity. Nonmyristoylated Abl variants did not associate with the plasma membrane in the transformed Ba/F3 cells. These results demonstrate that $A b l$ proteins can transform hematopoietic cells in the absence of membrane association and suggest that distinct functions of $\mathrm{Abl}$ are required for transformation of fibroblast and hematopoietic cell types.
\end{abstract}

Numerous proteins, including the viral and cellular forms of Src and Abl $(2,17,38,39)$, undergo myristoylation, a cotranslational modification that entails removal of the first methionine residue and attachment of a 14-carbon myristoyl fatty acid moiety to the resulting $\mathrm{N}$-terminal glycine $(2,29$, 45). The $\mathrm{N}$-terminal amino acid sequences of myristoylated proteins share only limited homology. The only absolute requirement is a glycine at the second position of the amino acid sequence (42). Mutagenesis of the $N$ terminus of Src defines a short stretch of some six residues that is sufficient to determine myristoylation $(1,4,18,31)$. These studies demonstrate that myristoylation is involved in targeting the Src protein to associate with the plasma membrane of cells and that this function is critical for the capacity of Src to transform fibroblast cell types (4). Membrane association plays a similar role in the transforming function of $\mathrm{Abl}$ protein variants. The myristoylated $\mathrm{v}$-Abl protein of Abelson murine leukemia virus transforms NIH 3T3 fibroblasts, but the nonmyristoylated $210-\mathrm{kDa} \mathrm{Bcr} / \mathrm{Abl}$ fusion protein $\left(\mathrm{P} 210^{b c r / a b l}\right)$ of chronic myelogenous leukemia cells does not $(7,24)$. Interestingly, attachment of myristoylated Gag sequences to the $\mathrm{N}$ terminus of $\mathrm{Bcr} / \mathrm{Abl}$ creates a $\mathrm{Gag} / \mathrm{Bcr} / \mathrm{Abl}$ protein that efficiently transforms NIH 3T3 fibroblasts (7). Though it fails to transform fibroblasts, $\mathrm{P} 210^{\text {bcrlabl }}$ readily transforms interleukin-3 (IL-3)-dependent hematopoietic cells to growth factor independence and tumorigenicity (5, 13) and induces a variety of hematopoietic neoplasms in mouse model systems $(8,9,14,15,21)$. These observations

\footnotetext{
* Corresponding author.

$\dagger$ Present address: Department of Genetics and Center for Blood Research, Harvard Medical School, Boston, MA 02115.

$\ddagger$ Present address: Department of Biochemistry and Biophysics, University of California at San Francisco, CA 94143.

$\S$ Present address: Department of Molecular Genetics, Massachusetts General Hospital Cancer Center, Charlestown, MA 02129.
}

suggest that myristoylation may not be as critical for transformation of hematopoietic cell types as it is for fibroblasts. To determine whether myristoylation is dispensable for hematopoietic cell transformation, myristoylation-defective mutants of $\mathrm{v}$-Abl and a transforming $\mathrm{SH} 3$ deletion mutant of c-Abl ( $\triangle \mathrm{XB}[17])$ were assayed for their capacity to mimic the biological activity of P210 ${ }^{b c r / a b l}$. Like P210 of the nonmyristoylated mutants transformed NIH 3T3 fibroblasts, but both retained the capacity to render the IL-3-dependent lymphoblastoid cell line Ba/F3 (30) growth factor independent and tumorigenic. The nonmyristoylated variants of $\mathrm{Abl}$ did not associate with the plasma membrane in $\mathrm{Ba} / \mathrm{F} 3$ cells. These results suggest that myristoylationdependent plasma membrane association is necessary for NIH 3T3 fibroblast transformation but not for the capacity of $\mathrm{Abl}$ protein variants to transform hematopoietic cells.

\section{MATERIALS AND METHODS}

Constructs and cell lines. The constructs used in these experiments were derivatives of the pucLJ retroviral vector (Fig. 1). The cDNA inserts for type IV c-Abl, the N-terminal type IV c-Abl deletion mutant $\triangle \mathrm{XB}$ (17), v-Abl, and $\mathrm{P} 210^{b c r / a b l}(5)$ have been described previously. A myristoylation-defective mutant of $\mathrm{v}$-Abl was made by oligonucleotide-directed mutagenesis of the glycine codon at amino acid position number two of the Moloney gag p15 sequences of v-abl. The GGC codon for glycine was mutated to GAC, which specifies an aspartic acid residue, resulting in an $\mathrm{N}$-terminal glycine-minus mutant of the $\mathrm{v}$-Abl protein $\left(\mathrm{Gly}^{-}\right.$ $\mathrm{v}$-Abl). In the same manner, a myristoylation-deficient mutant of the N-terminal type IV c-Abl deletion mutant $\Delta \mathrm{XB}$ (17) was constructed by oligonucleotide-directed mutagenesis. The Gly ${ }^{-} \Delta \mathrm{XB}$ construct is identical to wild-type $\Delta \mathrm{XB}$ except for a two-base-pair mutation in the second codon of the $a b l$ sequence which specifies an alanine residue (GCT) 


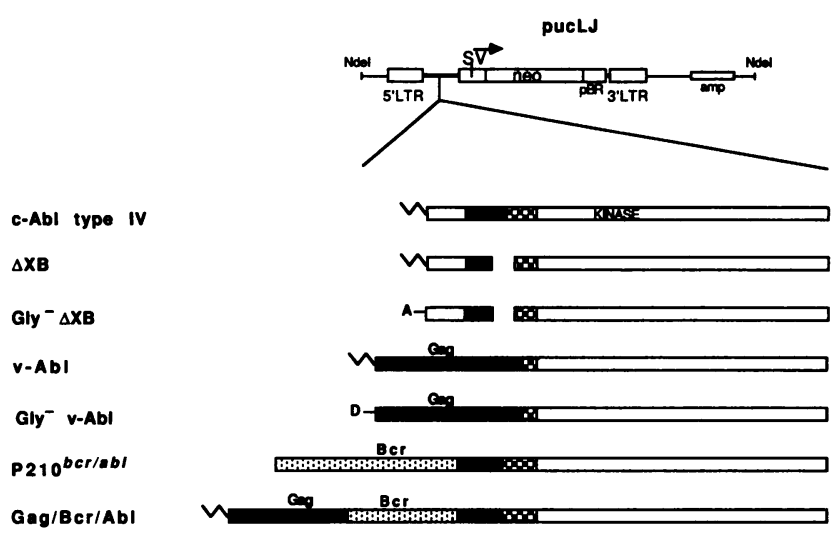

myristoyl fatty acid abl oxon 2 abl oxon 3

FIG. 1. Constructs for the expression of Abl proteins. The pucLJ vector is a derivative of $\mathrm{pLJ}$ (A. Korman and R. C. Mulligan, Whitehead Institute). The pucLJ vector expresses a cDNA insert from the 5 ' retroviral long terminal repeat (LTR) and a selectable marker gene (neo, encoding resistance to the antibiotic G418) from an internal simian virus 40 (SV) promoter. Coding sequences for several $\mathrm{Abl}$ protein variants were cloned into the vectors for use in expression studies in NIH 3T3 fibroblasts or IL-3-dependent $\mathrm{Ba} / \mathrm{F} 3$ cells. These constructs are shown schematically to illustrate the protein structures predicted for the cloned cDNA inserts. The $\mathrm{Gag} / \mathrm{Bcr} / \mathrm{Abl}$ protein derives from a recombinant viral isolate (7) and is shown here for structural comparison. A cloned facsimile has been described elsewhere (44).

instead of glycine (GGG). Because of the absolute substrate specificity of eukaryotic $N$-myristoyltransferases for $\mathrm{N}$-terminal glycine $(41,42)$, the $\mathrm{Gly}^{-} \mathrm{v}-\mathrm{Abl}$ and $\mathrm{Gly}^{-} \Delta \mathrm{XB} \mathrm{N}$ termini cannot be myristoylated. The constructs were assayed for their capacity to transform NIH 3T3 fibroblasts by one of the following two methods. Either constructs were cotransfected with a plasmid specifying Moloney helper virus (pZAP) onto NIH 3T3 cells, or a helper-free retroviral producer line was generated and viral supernatant was used to infect NIH 3 T3 cells. Helper-free producer lines were created by electroporating a linearized plasmid construct into $\psi$-2 cells (26) and selecting for stable integrants in G418 $(1 \mathrm{mg} / \mathrm{ml})$. The transfected or infected NIH 3T3 cells were grown to confluence and scored for the appearance of transformed foci after 14 days. Transformation was assessed by the capacity to form foci of rounded, refractile cells above a flat, confluent monolayer. For cells that appeared morphologically transformed, anchorage-independent growth was verified by the ability to form colonies when suspended in semisolid medium containing Bacto-Agar (0.3\%). Constructs were introduced by electroporation into the IL-3-dependent lymphoblastoid cell line Ba/F3 (30). For electroporation, $2 \times$ $10^{6}$ to $5 \times 10^{6}$ cells were washed and resuspended in $1 \mathrm{ml}$ of phosphate-buffered saline; 20 to $40 \mu \mathrm{g}$ of linear plasmid DNA in Tris-EDTA was added to the cells, and electroporation was performed in a Bio-Rad Gene Pulser $(960 \mu \mathrm{F}, 250$ $\mathrm{mV})$. Electroporated cells were kept on ice for $5 \mathrm{~min}$ and then transferred directly to growth media. Cells were grown for 2 days prior to selection in G418 (2 mg/ml). G418resistant populations were washed twice in phosphate-buffered saline and then split into media lacking a source of IL-3 in order to select for factor-independent growth. The criteria for autonomous growth in the absence of IL-3 and tumorigenicity in nude mice were previously described (5).
Immunoprecipitation. Cell lysates were incubated with anti-Abl antisera (pEX4 and pEX5) and processed for an in vitro immune complex kinase assay as previously described (22). Immunoprecipitated proteins were displayed by sodium dodecyl sulfate (SDS)-polyacrylamide gel electrophoresis and visualized by autoradiography. Equivalent numbers of cells were processed for each lane.

Immunofluorescence. Fibroblasts were grown on glass coverslips and then fixed and permeabilized in methanol and acetone as described previously (43). Ba/F3 cells were pelleted onto coverslips by cytocentrifugation (Shandon Instruments) and fixed in ethanol-acetic acid (3:1) for $15 \mathrm{~min}$ at room temperature and then in $95 \%$ ethanol for $5 \mathrm{~min}$ at room temperature, and then were air dried. The primary antibody was a mixture of crude anti-Abl sera (pEX4 and pEX5). The secondary antibody was a rhodamine-conjugated donkey anti-rabbit immunoglobulin G.

\section{RESULTS}

Nonmyristoylated Abl variants do not induce transformed foci on NIH 3T3 fibroblasts. The myristoylated v-Abl protein readily transforms NIH 3T3 fibroblasts (37), but expression of the normal type IV c-Abl protein from a similar retroviral context does not $(10,17)$. An internal deletion of 53 amino acids near the $\mathbf{N}$ terminus of type IV c-Abl (called $\Delta X B$ ) is sufficient to generate a transforming Abl protein (17). The $\Delta \mathrm{XB}$ deletion maintains the $\mathrm{N}$-terminal glycine of type IV c-Abl and encodes a myristoylated protein. To determine whether N-terminal myristoylation is required for $\mathrm{Abl}$ proteins to transform NIH 3 T3 fibroblasts, glycine-minus mutants of the $\mathrm{v}-\mathrm{Abl}$ and $\Delta \mathrm{XB}$ proteins were introduced into NIH 3 T3 fibroblasts. Virus from helper-free retroviral producer lines made with wild type $\mathrm{v}$-abl caused the morphologic transformation of NIH 3T3 cells $\left(>10^{2}\right.$ foci per ml), but viral stocks made with the mutant $\mathrm{Gly}^{-} \mathrm{v}-a b l$ construct failed to induce focus formation upon infection of NIH 3T3 fibroblasts ( $<1$ focus per $\mathrm{ml}$; Table 1 ). Both the wild-type and $\mathrm{Gly}^{-} \mathrm{v}-\mathrm{abl}$ mutant viruses passed the marker for resistance to the antibiotic G418 (approximately $4 \times 10^{4} \mathrm{G} 418$ $\mathrm{CFU} / \mathrm{ml}$ ) and induced expression of a $160-\mathrm{kDa}$ phosphoprotein in infected cells (data not shown). Expression of the myristoylation-defective $\mathrm{Gly}^{-} \Delta \mathrm{XB}$ protein in NIH $3 \mathrm{~T} 3$ cells likewise did not yield transformed foci $(<1$ focus per $\mu \mathrm{g}$ of plasmid), in contrast with the myristoylated $\triangle \mathrm{XB}$ construct, which efficiently transformed NIH 3T3 fibroblasts $\left(>10^{2}\right.$ foci per $\mu \mathrm{g}$ of plasmid). We experienced difficulty in isolating nontransformed cell lines that expressed high levels of either of the $\mathrm{Gly}^{-} \mathrm{Abl}$ proteins. However, as shown below, the constructs specifying $\mathrm{Gly}^{-} \mathrm{v}-\mathrm{Abl}$ and $\mathrm{Gly}^{-} \Delta \mathrm{XB}$ express the proteins efficiently in $\mathrm{Ba} / \mathrm{F} 3$ cells.

Transformation of IL-3-dependent Ba/F3 cells by myristoylated $\mathrm{Abl}$ protein variants. Constructs specifying various $\mathrm{Abl}$ proteins were introduced into $\mathrm{Ba} / \mathrm{F} 3$ cells by electroporation (to avoid complications of retroviral recombination). Cell lines resistant to the antibiotic G418 were isolated and tested for their capacity to grow in the absence of growth factor. Introduction into $\mathrm{Ba} / \mathrm{F} 3$ cells of an empty vector specifying resistance to G418 or one specifying the normal type IV c-Abl protein yielded G418-resistant cell lines that retained their dependence on exogenous IL-3 for growth. Previously, it had been demonstrated that the $\mathrm{V}$-Abl protein could render $\mathrm{Ba} / \mathrm{F} 3$ cells factor independent (27). In a similar manner, $\mathrm{Ba} / \mathrm{F} 3$ cells that express the $\triangle \mathrm{XB}$ protein could be selected to grow in the absence of IL-3. This factor-independent cell line expressing $\triangle \mathrm{XB}$ was tumorigenic in nude mice (Table 1). 
TABLE 1. Properties of NIH 3 T3 fibroblasts and $\mathrm{Ba} / \mathrm{F} 3$ cells expressing Abl protein variants

\begin{tabular}{|c|c|c|c|}
\hline Protein & $\begin{array}{c}\text { Transforms } \\
\text { NIH 3T3 } \\
\text { cells }^{a}\end{array}$ & $\begin{array}{c}\text { Renders } \mathrm{Ba} / \mathrm{F} 3 \\
\text { cells factor } \\
\text { independent }^{b}\end{array}$ & $\begin{array}{l}\text { Tumorigenic in nude } \\
\text { mice }^{c} \text { (no. of mice } \\
\text { with tumors/no. } \\
\text { challenged) }\end{array}$ \\
\hline $\begin{array}{l}\text { c-Abl type IV } \\
\Delta X^{-} \\
\mathrm{Gly}^{-} \Delta \mathrm{XB} \\
\text { V-Abl } \\
\mathrm{Gly}^{-} \mathrm{V}-\mathrm{Abl} \\
\mathrm{P} 210^{\text {bcr/abl }}\end{array}$ & $\begin{array}{l}\text { No } \\
\text { Yes } \\
\text { No } \\
\text { Yes } \\
\text { No } \\
\text { No }\end{array}$ & $\begin{array}{l}\text { No } \\
\text { Yes } \\
\text { Yes } \\
\text { Yes } \\
\text { Yes } \\
\text { Yes }\end{array}$ & $\begin{array}{l}\text { No }(0 / 5) \\
\text { Yes }(3 / 3) \\
\text { Yes }(2 / 2) \\
\text { Yes }(9 / 9) \\
\text { Yes }(3 / 3) \\
\text { Yes }(12 / 12)\end{array}$ \\
\hline
\end{tabular}

${ }^{a}$ The properties of type IV c-Abl, $\triangle \mathrm{XB}$, and P210 $0^{\text {br/abl }}$ in fibroblasts $(7,17)$ and of wild-type $\mathrm{v}$-Abl and $\mathrm{P} 210^{\text {bcrlabl }}$ in $\mathrm{Ba} / \mathrm{F} 3$ cells (5) were described previously. For the wild-type v-abl, Gly ${ }^{-} \mathrm{v}-a b l$, and $\mathrm{P} 210^{b c r / a b l}$ constructs, focus-forming titers were compared in a helper virus-free system. In the presence of helper virus, the $\mathrm{Gly}^{-} \mathrm{v}-a b l$ construct underwent recombination to yield small numbers of transformed foci that carried novel Gag/Abl fusion proteins of altered size (data not shown), reminiscent of the generation of the $\mathrm{Gag} / \mathrm{Bcr} / \mathrm{Abl}$ transforming variant (7).

${ }^{b}$ Electroporated $\mathrm{Ba} / \mathrm{F} 3$ cells were first selected in $\mathrm{G} 418$ at $2 \mathrm{mg} / \mathrm{ml}$ and then split into media lacking a source of IL-3 in order to select for factorindependent cell growth. Cell lines from which no factor-independent clones arose were weaned off IL-3 gradually in an attempt to select for clones with intermediate requirements for IL-3. Only cell lines which proliferated in the complete absence of exogenous IL-3 had a stable phenotype. By examining conditioned medium from the factor-independent cell lines, it was determined that none produced a growth factor that could support the proliferation of the parental $\mathrm{Ba} / \mathrm{F} 3$ cell line.

${ }^{c}$ Factor-dependent and -independent $\mathrm{Ba} / \mathrm{F} 3$ cell lines were injected subcutaneously into nude mice as described previously (5). Animals were observed for the development of large nonregressing malignant tumors. Cell lines were considered nontumorigenic if the injected mice remained tumor-free for several months.

Transformation of $\mathbf{B a} / \mathbf{F 3}$ cells by nonmyristoylated $\mathbf{A b l}$ proteins. To determine whether myristoylation is required for the ability of $v-\mathrm{Abl}$ and $\Delta \mathrm{XB}$ to transform $\mathrm{Ba} / \mathrm{F} 3$ cells, constructs specifying $\mathrm{Gly}^{-}$variants of these proteins were introduced into $\mathrm{Ba} / \mathrm{F} 3$ cells. G418-resistant cell populations were selected in media lacking a source of IL-3, and factorindependent cell lines were obtained, each of which formed tumors when injected into nude mice (Table 1).

Abl expression in $\mathbf{B a} / \mathbf{F 3}$ cell lines. $\mathrm{Ba} / \mathrm{F} 3$ cell lines were analyzed to determine whether Abl proteins of the predicted size were being expressed. Cell extracts were immunoprecipitated with antisera directed against $\mathrm{C}$-terminal $\mathrm{Abl}$ determinants and processed for in vitro immune complex kinase assay (22). Denaturing polyacrylamide gel electrophoresis followed by autoradiography allowed for the detection of the expected protein in each of the tested samples (Fig. 2). To verify that the $\mathrm{Gly}^{-} \mathrm{V}$-Abl protein expressed in factorindependent $\mathrm{Ba} / \mathrm{F} 3$ cell lines indeed lacked myristoylation, $\mathrm{Ba} / \mathrm{F} 3$ cell lines expressing $\mathrm{Gly}^{-} \mathrm{v}-\mathrm{Abl}, \mathrm{P} 210^{\text {bcr/abl, }}$, and wild-type $\mathrm{v}$-Abl were metabolically labelled with either $\left[{ }^{35} \mathrm{~S}\right]$ methionine or $\left[{ }^{3} \mathrm{H}\right]$ myristate, immunoprecipitated with anti-Abl antisera, separated by denaturing polyacrylamide gel electrophoresis, and analyzed by autoradiography. Cells labelled with $\left[{ }^{35} \mathrm{~S}\right]$ methionine expressed the relevant $\mathrm{Abl}$ protein forms (Fig. 3A), but only the wild-type $\mathrm{v}$-Abl protein incorporated the $\left[{ }^{3} \mathrm{H}\right]$ myristate label (Fig. 3B). Incorporation of $\left[{ }^{3} \mathbf{H}\right]$ myristate into the transforming protein was not detected in the cells expressing the Gly ${ }^{-} \mathrm{V}$-Abl or P210 bcr/abl protein, although twice as many cells expressing $\mathrm{Gly}^{-} \mathrm{v}-\mathrm{Abl}$ were labelled as for the wild-type v-Abl. Moreover, the structure of the $\mathrm{Gly}^{-} \mathrm{v}-\mathrm{abl}$ construct introduced into the $\mathrm{Ba} / \mathrm{F} 3$ cells was analyzed by Southern hybridization and shown to be unrearranged (data not shown). These results

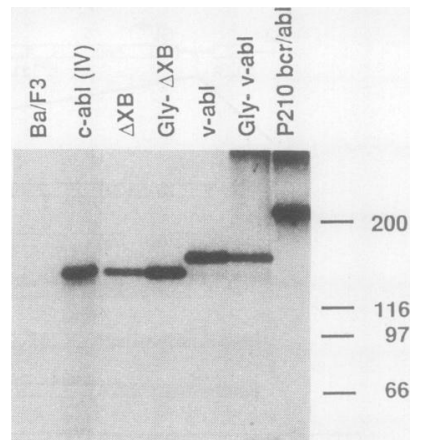

FIG. 2. Immunoprecipitation analysis of $\mathrm{Ba} / \mathrm{F} 3$ cell lines expressing Abl protein variants. Lanes (from left to right) contained samples as follows. Uninfected $\mathrm{Ba} / \mathrm{F} 3$ cells and a $\mathrm{Ba} / \mathrm{F} 3$ cell line expressing the type IV c-Abl protein were maintained in medium supplemented with WEHI-3B conditioned medium as a source of IL-3; Ba/F3 cell lines expressing the $\Delta \mathrm{XB}, \mathrm{Gly}^{-} \Delta \mathrm{XB}, \mathrm{v}-\mathrm{Abl}, \mathrm{Gly}^{-}$ $\mathrm{v}-\mathrm{Abl}$, and $\mathrm{P} 210^{\mathrm{bcr} / a b l}$ proteins were all factor independent and could be maintained in media without added IL-3. The first two lanes were taken from an independent experiment run under conditions comparable to those used for the other lanes. Sizes are shown in kilodaltons.

indicate that the $\mathrm{Gly}^{-} \mathrm{v}$-Abl protein expressed in $\mathrm{Ba} / \mathrm{F} 3$ cells lacks the myristoyl moiety. Myristoylation does not appear to be required for $\mathrm{Abl}$ proteins to transform the hematopoietic cell line $\mathrm{Ba} / \mathrm{F} 3$.

Immunofluorescent localization of myristoylated and nonmyristoylated Abl proteins. The subcellular localization of various myristoylated and nonmyristoylated $\mathrm{Abl}$ protein forms was assessed by indirect immunofluorescence. When

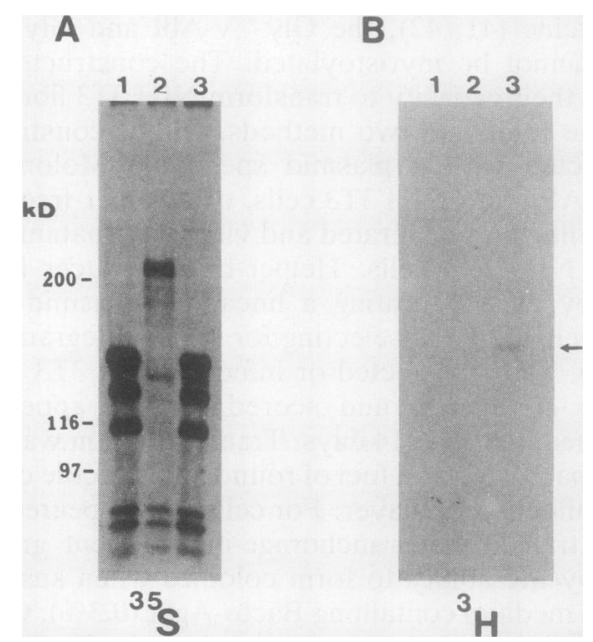

FIG. 3. Immunoprecipitation analysis of metabolically labelled, factor-independent $\mathrm{Ba} / \mathrm{F} 3$ cell lines. Cell lines expressing the $\mathrm{Gly}^{-}$ $\mathrm{v}$-Abl (lane 1), P210 bcrlabl (lane 2), and wild-type v-Abl (lane 3) proteins were labelled with either $\left.{ }^{35} S\right]$ methionine for $4 \mathrm{~h}(\mathrm{~A})$ or $\left[{ }^{3} \mathrm{H}\right]$ myristate for $25 \mathrm{~min}(\mathrm{~B})$ and processed for immunoprecipitation analysis with anti-Abl antisera (pEX4 and pEX5). Twice as many cells were processed for the $\mathrm{Gly}^{-} \mathrm{v}$-Abl mutant than for samples in the other lanes. Proteins were displayed by SDS-polyacrylamide gel electrophoresis and visualized by autoradiography. Panel A was exposed for $24 \mathrm{~h}$. The prominent proteins of 116 and $140 \mathrm{kDa}$ in lanes 1 and 3 represent proteolytic breakdown products of the $160-\mathrm{kDa} \mathrm{V}-\mathrm{Abl}$ protein frequently observed in these preparations. The gel in panel B was soaked in Autofluor, dried, and exposed for 72 days. The arrow denotes the position of the $160-\mathrm{kDa}$ $\left[{ }^{3} \mathrm{H}\right]$ myristate-labelled $\mathrm{v}$-Abl protein. 
expressed in NIH 3T3 fibroblasts, the nontransforming, nonmyristoylated $\mathrm{P} 210^{\text {bcr/abl }}$ and $\mathrm{Gly}^{-} \mathrm{v}$-Abl proteins localized to the cytoplasm and were not detectably associated with the plasma membrane (Fig. 4C and G). An association of the $\mathrm{P} 210^{\text {bcr/abl }}$ protein with actin filaments was apparent, as described previously $(28,43)$. The transforming, myristoylated $\mathrm{Gag} / \mathrm{Bcr} / \mathrm{Abl}$ and $\mathrm{v}$-Abl variants, on the other hand, associated in part with the plasma membrane (Fig. 4A and E). These results argue that the presence of the myristoyl moiety targeted a portion of the Abl protein to associate with the plasma membrane in NIH 3T3 fibroblasts. To examine the possibility that the various Abl proteins might localize differently in hematopoietic cells, their subcellular distribution was determined in $\mathrm{Ba} / \mathrm{F} 3$ cells. The myristoylated proteins $\mathrm{v}$-Abl and $\triangle \mathrm{XB}$ were mainly cytoplasmic but associated in part with the plasma membrane (Fig. 5A and C). By contrast, the nonmyristoylated $\mathrm{Gly}^{-} \mathrm{v}-\mathrm{Abl}, \mathrm{Gly}^{-} \Delta \mathrm{XB}$, and P210 bcrlabl proteins showed only a cytoplasmic distribution and lacked the prominent plasma membrane staining (Fig. $5 B, D$, and F).

\section{DISCUSSION}

Myristoylation and transformation. The nonmyristoylated P210 bcrlabl protein associated with human chronic myelogenous leukemia readily transforms hematopoietic cell types in culture and in animal model systems (6), suggesting that myristoylation is not critical for the transforming activity of $\mathrm{Abl}$ proteins in hematopoietic cells. To verify this hypothesis, we created two nonmyristoylated point mutants of transforming Abl proteins, Gly ${ }^{-} \mathrm{v}-\mathrm{Abl}$ and $\mathrm{Gly}^{-} \Delta \mathrm{XB}$, and showed that these forms behaved similarly to P210 bcrlabl, i.e., they failed to transform NIH 3T3 fibroblasts but retained the capacity to transform the IL-3-dependent hematopoietic cell line $\mathrm{Ba} / \mathrm{F} 3$. The subcellular localization of the various myristoylated and nonmyristoylated $\mathrm{Abl}$ variants argues that myristoylation targets some portion of the Abl protein to associate intimately with the cell's plasma membrane. The results presented above and in a previous study (7) suggest that myristoylation is required for $\mathrm{Abl}$ protein variants to transform NIH 3T3 fibroblasts. However, myristoylation-dependent membrane association appears irrelevant for transformation of hematopoietic cells.

Our attempts to generate stable nontransformed NIH 3T3 fibroblast cell lines that express high levels of the nonmyristoylated $\mathrm{Gly}^{-} \mathrm{Abl}$ variants proved unsuccessful, owing to the known toxicity of Abl proteins (46). Thus, we cannot rigorously exclude the possibility that myristoylation-deficient forms of the Abl protein might transform NIH 3T3 fibroblasts if high enough levels of protein could be stably achieved. However, we believe this to be unlikely, because even high levels of the $\mathrm{P} 210^{\text {bcrlabl }}$ protein fail to transform NIH 3T3 cells $(7,23)$. We are more compelled by the likelihood that myristoylation-dependent membrane association is critical for transformation of NIH 3T3 fibroblasts because of the particular transformation requirements of this adherent cell type. Alternatively, nonmyristoylated variants may be inherently unstable in NIH 3T3 fibroblasts or more stable in $\mathrm{Ba} / \mathrm{F} 3$ cells. P210 $0^{\text {bcr/abl }}$ is weakly transforming for Rat-1 fibroblasts (23). It would be interesting to determine whether $\mathrm{Bcr} / \mathrm{Abl}$ or other nonmyristoylated $\mathrm{Abl}$ variants associate with the plasma membrane or are more stable in Rat-1 cells, or whether distinct substrates are phosphorylated.

Role of membrane-associated and cytosolic forms of $\mathrm{Abl}$ in transformation. Phosphorylation of membrane-associated components that mediate contact inhibition may be critical for the transformation of anchorage-dependent cell types (16) and thus may be facilitated by targeting of transforming protein kinases to the plasma membrane by myristoylation. Integral membrane proteins that are phosphorylated only by myristoylated Src variants have been identified by using antisera directed against phosphotyrosine $(12,36)$. Other candidate protein substrates include elements of signal transduction pathways. Activated Abl proteins like P210 bcrlabl, $\mathrm{Gag} / \mathrm{Bcr} / \mathrm{Abl}$, v-Abl, and $\Delta \mathrm{XB}$ associate with a phosphatidylinositol $3^{\prime}$-kinase in fibroblasts, but only the membrane-associated transforming variants lead to increased steady-state levels of the 3 '-phosphorylated lipid phosphatidylinositol trisphosphate (44), perhaps because of accessibility to phospholipid substrates. Phosphatidylinositol trisphosphate levels correlate with mitogenesis in fibroblasts. Activation of lipid kinase pathways may be one means by which transforming Abl proteins undermine normal growth control.

Factor-dependent hematopoietic cell types such as $\mathrm{Ba} / \mathrm{F} 3$ grow in suspension culture and are not subject to the constraints of contact inhibition. Instead, regulation of cell proliferation in circulating hematopoietic cells occurs in response to diffusible growth factors. By phosphorylating some component of the IL-3 signal transduction pathway in $\mathrm{Ba} / \mathrm{F} 3$ cells, the $\mathrm{Abl}$ kinase may override the requirement for exogenous growth factor and constitutively signal cell proliferation. The critical substrate for transformation in this case may be cytosolic and accessible to nonmyristoylated forms of $\mathrm{Abl}$. Interestingly, stimulation of cell proliferation can be separated from transformation for nonmyristoylated forms of Src. Nonmyristoylated Src proteins have mitogenic activity for cells in culture, suggesting that the targets for induction of cell proliferation are accessible to nonmyristoylated Src protein $(3,19)$. Simply activating the Abl kinase appears sufficient to transform $\mathrm{Ba} / \mathrm{F} 3$ cells in the absence of myristoylation-dependent membrane association. However, it appears that two functions are necessary for transformation of NIH 3T3 fibroblasts: a kinase activity that activates an intracellular mitogenic pathway, and membrane association which enables the kinase to phosphorylate as yet undefined membrane substrates in order to undermine contact inhibition. Myristoylation provides one means of targeting $\mathrm{Abl}$ proteins to associate with the plasma membrane. Fusion of the v-Abl kinase domain with the transmembrane domain of the epidermal growth factor receptor provides another such means and results in a protein that readily transforms fibroblasts in culture (32).

Role of the myristoyl moiety in protein targeting. It is unlikely that the hydrophobicity of the acyl moiety alone mediates the association of myristoylated proteins with membranes. A significant fraction of myristoylated proteins can be found soluble in the cell $(2,25,29)$. Moreover, the association of the myristoylated alanine-rich C-kinase substrate with the plasma membrane is reversibly regulated by phosphorylation, and its distribution is concentrated in adhesion plaques (40), arguing that the protein associates with a specific receptor rather than through nonspecific insertion of the lipid moiety in the membrane bilayer. Myristoylation alone is not sufficient to specify the subcellular locale of Src. Interestingly, Src associates chiefly with the plasma membrane in fibroblasts but with other cellular membranes in distinct cell types (e.g., growth cones in neurons). Certain domains of the Src $\mathrm{N}$ terminus complement the myristoylation function in directing the protein to particular subcellular locations (20). Myristoylation may serve as a ligand for 


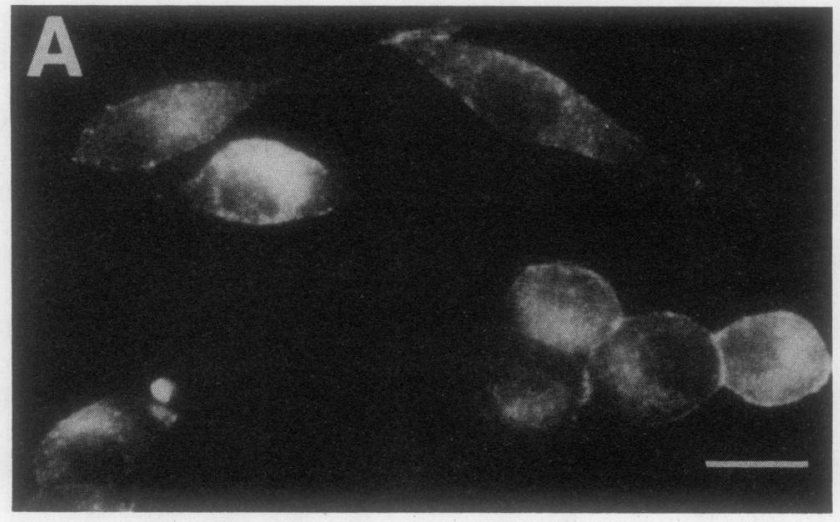

\section{무}

FIG. 4. Indirect immunofluorescence of NIH 3T3 fibroblasts expressing Abl protein variants. (A) Transformed cells expressing the myristoylated v-Abl protein; (B) nonimmune primary antiserum control for panel A. (C) nontransformed cells expressing the nonmyristoylated $\mathrm{Gly}^{-} \mathrm{v}$-Abl protein (analysis was performed on an unstable clone that was undergoing loss of expression of the Abl protein); (D) nonimmune primary antiserum control for panel C; (E) transformed cells expressing the myristoylated P220 Gag/Bcr/Abl protein (7); (F) nonimmune primary antiserum control for panel E; $(\mathrm{G})$ nontransformed cells expressing the nonmyristoylated P210 ${ }^{b c r / a b l}$ protein; $(\mathrm{H})$ nonimmune primary antiserum control for panel G. Note the accentuated membrane staining at areas of cell-cell contact in panels A and E.

membrane-associated receptors or docking proteins that determine specific membrane destinations within the cell $(11,33)$. In support of this notion, Resh $(33,34)$ and Resh and Ling (35) have identified a plasma membrane myristoyl receptor which binds the Src protein. Myristoylation apparently targets only a portion of the type IV c-Abl protein in the cell to associate with the plasma membrane. The stoichiometry of myristoylation of Abl protein has not been
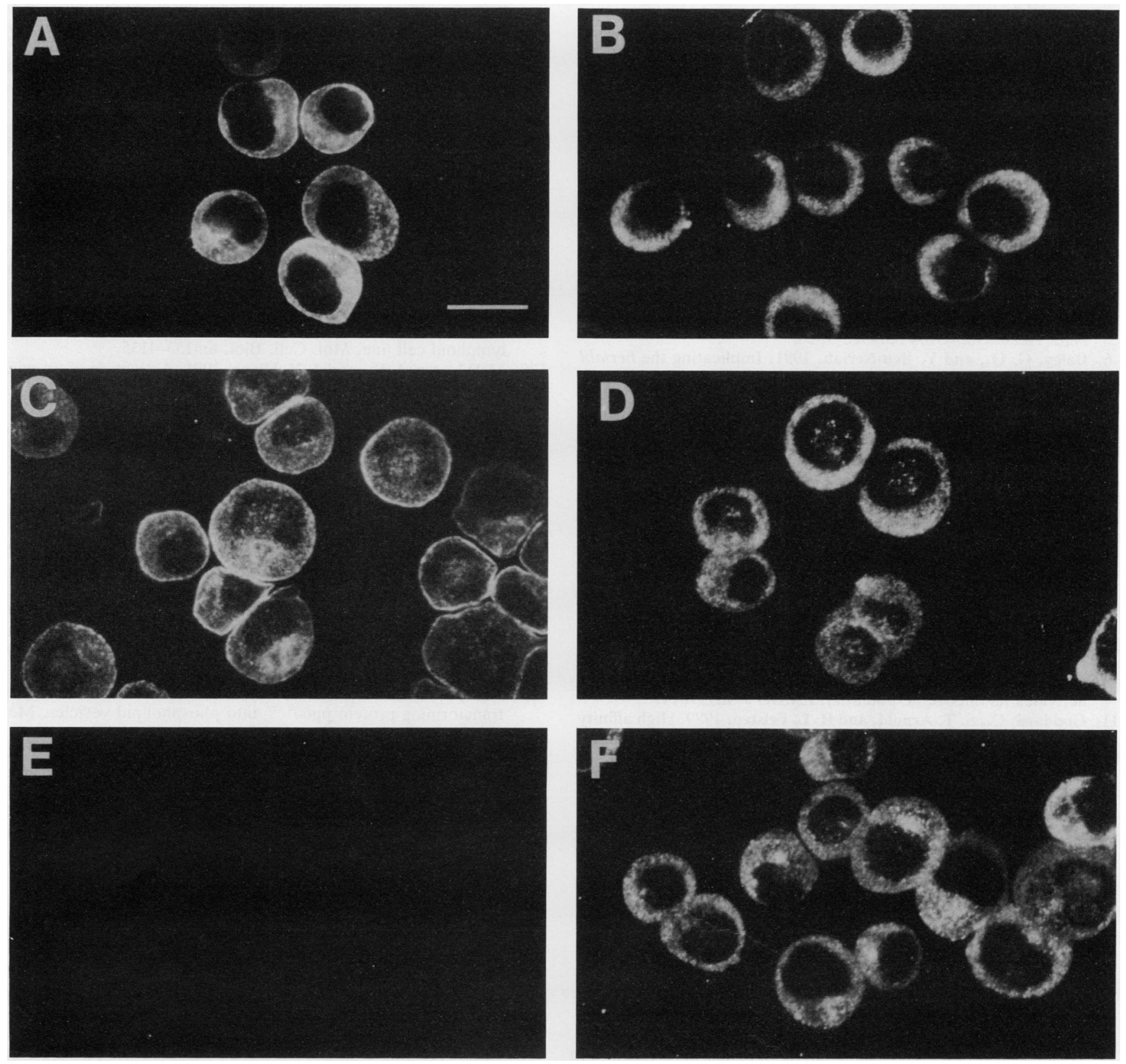

FIG. 5. Indirect immunofluorescence of $\mathrm{Ba} / \mathrm{F3}$ cells expressing Abl protein variants. (A) Myristoylated wild-type v-Abl protein; (B) nonmyristoylated $\mathrm{Gly}^{-} \mathrm{v}$-Abl protein; (C) myristoylated $\Delta \mathrm{XB}$ protein; (D) nonmyristoylated $\mathrm{Gly}^{-} \Delta \mathrm{XB}$ protein; (E) parental Ba/F3 cells (control); (F) nonmyristoylated $\mathrm{P} 210^{b c r l a b l}$ protein. Note prominent membrane staining in panels A and C. Membrane staining is lacking in panels B, D, and F. 
determined, but it is highly plausible that myristoyl-Abl receptors serve to partition Abl proteins in various compartments within the cell. Myristoylation appears to be a necessary but not sufficient signal for membrane localization, a switch regulated in ways not yet understood.

\section{ACKNOWLEDGMENTS}

This work was funded in part by NIH grant CA51462-02 and by a grant from the Lucille P. Markey Charitable Trust to R.A.V.

\section{REFERENCES}

1. Buss, J. E., C. J. Der, and P. A. Solski. 1988. The six aminoterminal amino acids of $\mathrm{p} 60^{s r c}$ are sufficient to cause myristylation of p21 v-ras. Mol. Cell. Biol. 8:3960-3963.

2. Buss, J. E., M. P. Kamps, and B. M. Sefton. 1984. Myristic acid is attached to the transforming protein of Rous sarcoma virus during or immediately after synthesis and is present in both soluble and membrane-bound forms of the protein. Mol. Cell. Biol. 4:2697-2704.

3. Calothy, G., D. Laugier, F. R. Cross, R. Jove, T. Hanafusa, and H. Hanafusa. 1987. The membrane-binding domain and myristylation of $\mathrm{p}^{\mathrm{v}-\mathrm{src}}$ are not essential for stimulation of cell proliferation. J. Virol. 61:1678-1681.

4. Cross, F. R., E. A. Garber, D. Pellman, and H. Hanafusa. 1984. A short sequence in the p60 $60^{s r c} \mathrm{~N}$ terminus is required for $\mathrm{p} 60^{\text {src }}$ myristylation and membrane association and for cell transformation. Mol. Cell. Biol. 4:1834-1842.

5. Daley, G. Q., and D. Baltimore. 1988. Transformation of an interleukin 3-dependent hematopoietic cell line by the chronic myelogenous leukemia-specific P210 bcr/abl protein. Proc. Natl. Acad. Sci. USA 85:9312-9316.

6. Daley, G. Q., and Y. Ben-Neriah. 1991. Implicating the bcr/abl gene in the pathogenesis of Philadelphia chromosome-positive human leukemia., p. 151-184. In G. Vande Woude and G. Klein (ed.), Advances in cancer research. Academic Press, Inc., San Diego, Calif.

7. Daley, G. Q., J. McLaughlin, O. N. Witte, and D. Baltimore. 1987. The CML-specific P210 bcr/abl protein, unlike v-abl, does not transform NIH/3T3 fibroblasts. Science 237:532-535.

8. Daley, G. Q., R. A. Van Etten, and D. Baltimore. 1990. Induction of chronic myelogenous leukemia in mice by the P210 bcr/abl gene of the Philadelphia chromosome. Science 247:824 830.

9. Elefanty, A. G., I. K. Hariharan, and S. Cory. 1990. bcr-abl, the hallmark of chronic myeloid leukemia in man, induces multiple hematopoietic neoplasms in mice. EMBO J. 9:1069-1078.

10. Franz, W. M., P. Berger, and J. Y. J. Wang. 1989. Deletion of an $\mathrm{N}$-terminal regulatory domain of the $\mathrm{c}$ - $a b l$ tyrosine kinase activates its oncogenic potential. EMBO J. 8:137-147.

11. Goddard, C., S. T. Arnold, and R. L. Felsted. 1989. High affinity binding of an N-terminal myristoylated p60src peptide. J. Biol. Chem. 264:15173-15176.

12. Hamaguchi, M., M. Matsuda, and H. Hanafusa. 1990. A glycoprotein in the plasma membrane matrix as a major potential substrate of p60 v-src . Mol. Cell. Biol. 10:830-836.

13. Hariharan, I. K., J. M. Adams, and S. Cory. 1988. bcr-abl oncogene renders myeloid cell line factor independent: potential autocrine mechanism in chronic myeloid leukemia. Oncogene Res. 3:387-399.

14. Hariharan, I. K., A. W. Harris, M. Crawford, H. Abud, E. Webb, S. Cory, and J. M. Adams. 1989. A bcr-v-abl oncogene induces lymphomas in transgenic mice. Mol. Cell. Biol. 9:27982805.

15. Heisterkamp, N., G. Jenster, J. ten Hoeve, D. Zovich, P. K. Pattengale, and J. Grofien. 1990. Acute leukemia in bcr/abl transgenic mice. Nature (London) 344:251-253.

16. Hynes, R. O. 1987. Integrins: a family of cell surface receptors. Cell 48:549-554.

17. Jackson, P., and D. Baltimore. 1989. N-terminal mutations activate the leukemogenic potential of the myristoylated form of c-abl. EMBO J. 8:449-456.

18. Kamps, M. P., J. E. Buss, and B. M. Sefton. 1985. Mutation of $\mathrm{N}$-terminal glycine of $\mathrm{p} 60^{\text {src }}$ prevents both myristoylation and morphologic transformation. Proc. Natl. Acad. Sci. USA 82: $4625-4628$.

19. Kamps, M. P., J. E. Buss, and B. M. Sefton. 1986. Rous sarcoma virus transforming protein lacking myristic acid phosphorylates known polypeptide substrates without inducing transformation. Cell 45:105-112.

20. Kaplan, J. M., H. E. Varmus, and J. M. Bishop. 1990. The src protein contains multiple domains for specific attachment to membranes. Mol. Cell. Biol. 10:1000-1009.

21. Kelliher, M. A., J. McLaughlin, O. N. Witte, and N. Rosenberg. 1990. Induction of a chronic myelogenous leukemia-like syndrome in mice with v-abl and BCR/ABL. Proc. Natl. Acad. Sci. USA 87:6649-6653.

22. Konopka, J. B., and O. N. Witte. 1985. Detection of c-abl tyrosine kinase activity in vitro permits direct comparison of normal and altered $a b l$ gene products. Mol. Cell. Biol. 5:31163123.

23. Lugo, T. G., A.-M. Pendergast, A. J. Muller, and O. N. Witte. 1990. Tyrosine kinase activity and transformation potency of bcr-abl oncogene products. Science 247:1079-1082.

24. Lugo, T. G., and O. N. Witte. 1989. The bcr-abl oncogene transforms Rat-1 cells and cooperates with v-myc. Mol. Cell. Biol. 9:1263-1270.

25. Magee, A. I., and S. A. Courtneidge. 1985. Two classes of fatty acid acylated proteins exist in eukaryotic cells. EMBO J. 4:1137-1144.

26. Mann, R., R. C. Mulligan, and D. Baltimore. 1983. Construction of a retrovirus packaging mutant and its use to produce helperfree defective retrovirus. Cell 33:153-159.

27. Mathey-Prevot, B., G. Nabel, R. Palacios, and D. Baltimore. 1986. Abelson virus abrogation of interleukin-3 dependence in a lymphoid cell line. Mol. Cell. Biol. 6:4133-4135.

28. McWhirter, J. R., and J. Y. Wang. 1991. Activation of tyrosine kinase and microfilament-binding functions of c-abl by $b c r$ sequences in bcr/abl fusion proteins. Mol. Cell. Biol. 11:1553-1565.

29. Olson, E. N., and G. Spizz. 1986. Fatty acylation of cellular proteins. J. Biol. Chem. 261:2458-2466.

30. Palacios, R., and M. Steinmetz. 1985. IL3-dependent mouse clones that express B-220 surface antigen, contain Ig genes in germ-line configuration, and generate $B$ lymphocytes in vivo. Cell 41:727-734.

31. Pellman, D., E. A. Garber, F. R. Cross, and H. Hanafusa. 1985. Fine structural mapping of a critical $\mathrm{NH}_{2}$-terminal region of p60 src . Proc. Natl. Acad. Sci. USA 82:1623-1627.

32. Prywes, R., E. Livneh, A. Ullrich, and J. Schlessinger. 1986. Mutations in the cytoplasmic domain of EGF receptor affect EGF binding and receptor internalization. EMBO J. 5:2179 2190

33. Resh, M. D. 1988. Reconstitution of the Rous sarcoma virus transforming protein $\mathrm{pp} 60^{\mathrm{v}-\mathrm{src}}$ into phospholipid vesicles. Mol. Cell. Biol. 8:1896-1905.

34. Resh, M. D. 1989. Specific and saturable binding of $p p 60^{v-s r c}$ to plasma membranes: evidence for a myristyl-src receptor. Cell 58:281-286.

35. Resh, M. D., and H.-P. Ling. 1990. Identification of a 32K plasma membrane protein that binds to the myristylated aminoterminal sequence of p60v-src. Nature (London) 346:84-86.

36. Reynolds, A. B., D. J. Roesel, S. B. Kanner, and J. T. Parsons. 1989. Transformation-specific tyrosine phosphorylation of a novel cellular protein in chicken cells expressing oncogenic variants of the avian cellular src gene. Mol. Cell. Biol. 9:629 638.

37. Scher, C. D., and R. Siegler. 1975. Direct transformation of 3T3 cells by Abelson murine leukemia virus. Nature (London) 253:729-731.

38. Schultz, A., and S. Oroszlan. 1984. Myristylation of gag-onc fusion proteins in mammalian transforming retroviruses. Virology 133:431-437.

39. Schultz, A. M., L. E. Henderson, S. Oroszlan, E. A. Garber, and H. Hanafusa. 1985. Amino terminal myristylation of the protein 
kinase p60src, a retroviral transforming protein. Science 227: $427-429$.

40. Thelen, M., A. Rosen, A. C. Nairn, and A. Aderem. 1991. Regulation by phosphorylation of reversible association of a myristoylated protein kinase $C$ substrate with the plasma membrane. Nature (London) 351:320-322.

41. Towler, D. A., S. P. Adams, S. R. Eubanks, D. S. Towery, E. Jackson-Machelski, L. Glaser, and J. I. Gordon. 1987. Purification and characterization of yeast myristoyl CoA: protein $N$-myristoyltransferase. Proc. Natl. Acad. Sci. USA 84:27082712.

42. Towler, D. A., S. R. Eubanks, D. S. Towery, S. P. Adams, and L. Glaser. 1987. Amino-terminal processing of proteins by $N$-myristoylation. J. Biol. Chem. 262:1030-1036.
43. Van Etten, R. A., P. Jackson, and D. Baltimore. 1989. The mouse type IV c-abl gene product is a nuclear protein, and activation of transforming ability is associated with cytoplasmic localization. Cell 58:669-678.

44. Varticovski, L., G. Q. Daley, P. K. Jackson, D. Baltimore, and L. C. Cantley. 1991. Activation of phosphatidylinositol 3-kinase in cells expressing $a b l$ oncogene variants. Mol. Cell. Biol. 11:1107-1113.

45. Wilcox, C., J.-S. Hu, and E. N. Olson. 1987. Acylation of proteins with myristic acid occurs cotranslationally. Science 238:1275-1278.

46. Ziegler, S. F., C. A. Whitlock, S. P. Goff, A. Gifford, and O. N. Witte. 1981. Lethal effect of the Abelson murine leukemia virus transforming gene product. Cell 27:477-486. 